\title{
Streetcars and Economic Development: Do Streetcars Stimulate Employment Growth?
}

Sarah Jack Hinners, Ph.D

Director, Ecological Planning Center

Department of City and Metropolitan Planning

University of Utah

Salt Lake City, Utah

Arthur C. Nelson, Ph.D., FAcSS, FAICP

Professor of Planning and Real Estate Development

School of Landscape Architecture and Planning

University of Arizona

Tucson, Arizona

E: acnelson@ArthurCNelson.com

Martin Buchert, MA

Senior Research Analyst

Global Change and Sustainability Center

University of Utah

Salt Lake City, Utah

\section{Acknowledgements}

The authors acknowledge support for research reported in this article from the U.S. Department of Housing and Urban Development's Office of Policy Development and Research with assistance from the University of Utah, the National Institute for Transportation and Communities, and the University of Arizona. We recognize especially contributions from Richard Decker, Dejan Eskic, Emily Guffin, Michael Larice, Kate Morrell, and Cassie Younger. Views expressed herein do not necessarily reflect those of the research sponsor or the authors' universities.

The authors confirm contribution to the paper as follows: study conception and design: Hinners, Nelson, Buchert; data collection: Buchert; analysis and interpretation of results: Hinners, Nelson; draft manuscript preparation: Hinners, Nelson. All authors reviewed the results and approved the final version of the manuscript.

Text $\quad 5,840$

Tables 6 @ 250 words each

Words 7,340

March 2018 


\title{
Streetcars and Economic Development: Do Streetcars Stimulate Employment Growth?
}

\author{
Abstract \\ This study reports economic development outcomes — defined as change in employment—for \\ areas within one-quarter mile of three streetcar stations along four lines in each of four cities: \\ Portland OR; Salt Lake City UT; Seattle WA; and New Orleans LA. Employment three years \\ prior to the start of the streetcar construction was compared to employment within the three \\ streetcar station areas in 2013. Before-after comparisons are also applied to ten bus stops within \\ each urbanized area selected as "controls" because they are quantitatively comparable to each \\ streetcar station area studied. Shift-share analysis is used to compare each streetcar and control \\ station area's employment trends with respect to central county economic performance. \\ Portland's system showed strong economic development consistency followed by New Orleans. \\ The Salt Lake City and Seattle lines, however, did not perform as consistently. These results \\ indicate that while streetcar investment may support economic development, it is not alone a \\ driver of employment growth.
}




\section{Introduction: The American Streetcar Renaissance}

Prior to the opening of Portland, Oregon's North-South streetcar line in 2001, streetcars in North America were novelties - a charming relic of a bygone era found only in a handful of cities. Streetcars are now popping up all over North America, with about a dozen in operation and many more being planned. Until recently, it seemed that a true streetcar renaissance was taking place that would reshape public transportation in American cities. Streetcars have come under scrutiny lately which led in part to the cancellation of two streetcar projects in Arlington, Virginia in late 2014. The debate rages between those who see streetcars as transit projects and those who see streetcars as economic development and/or urban revitalization investments. This dichotomy of perspective is more than nuance, for it is essentially what shut down the Arlington streetcar project and "...destroyed 15 years of a joint effort...It set back transit options in this part of the region for at least a generation or more" (1).

Those in the anti-streetcar camp argue that as a way of moving people around, streetcars are excessively expensive and inefficient. They point out that streetcars are subject to getting stuck in traffic, do not move much faster than a person on foot or bicycle, yet require multimillion dollar infrastructure investments. The transportation needs of communities, they argue, would be better met by increasing bus service or by improving roads $(2,3)$. In a recent comparative study, Brown, Nixon and Ramos (4) note that with respect to operations costs, streetcars are a less efficient transit mode than buses.

The pro-streetcar camp argues that streetcars can be more than just transportation projects as they are highly visible investments that serve as a catalyst for economic development. For instance, Brown, Nixon and Ramos (4) note that Portland's streetcar system stood alone as a successful economic development and urban revitalization investment perhaps because it was 
planned to facilitate revitalization in addition to transportation. While a 2014 article in The Guardian speaks of the "emotional and aesthetic allure" of streetcars (5), and Brown, Nixon and Ramos (4) offer that streetcars "have now taken on an iconic role completely separate from any transportation function they possess" being, notably a catalyst for economic development.

This article is the first to systematically assess the economic development outcomes to streetcar investments. It does so through analysis of comparisons between streetcar lines built in Portland, Salt Lake City, Seattle, and New Orleans. It concludes with an interpretation of the applications and implications of the results for understanding the relationship between streetcars and employment.

\section{Streetcars and Economic Development}

Because they are so new, there are very few comparative, objective studies on the linkage between streetcars and economic development. Existing studies are either single-city case studies $(6,7)$, and/or non-peer-reviewed reports commissioned and published by interested parties ( 8 ) such as transit agencies.

As the relationship between transportation investments and economic development is one of the most-researched topics in urban planning, we focus on a few recent perspectives relevant to this article. Nelson et al. (9) lay out a series of economic arguments in favor of transit investments such as facilitating agglomeration economies, increasing real estate values and enhancing connectivity between people and jobs. Higgins and Kanaroglou (10) note that while transit are assumed to generate positive economic outcomes such as increasing real estate values near transit stations, 40 years of research on the topic shows considerable variation across cities, transit modes, and even stations. Kolko surmises that, "The relationship between transit and 
surrounding land values and densities depends both on how businesses and residents value proximity to transit and on public-sector decisions about zoning, land use, and other incentives for transit-oriented development" (11). As a case in point, a study of projected outcomes to streetcar investments in Cincinnati found that impacts were spatially limited without accompanying policies designed to stimulate economic development (12).

To assess directly the extent to which jobs are attracted to transit investments, Nelson et al (13) studied the Eugene-Springfield, Oregon BRT system, finding enhanced growth in employment relative to the rest of the metropolitan area within 0.25 miles of BRT stations. This growth was not consistent across job sectors however, a finding that is supported by Belzer et al.'s (14) analysis of preferences of different employment sectors to locate near transit infrastructure. In contrast, Kolko examined 204 rail transit stations in California and found that growth in employment near stations was variable, with more station areas losing jobs than gaining (11).

These and other studies show transit investments do not automatically lead to economic development. And outcomes may vary by transit mode. Notably, compare to LRT and BRT systems, streetcars are much slower as they tend to move in traffic at the speed of traffic —often little faster than walking. Streetcars also stop more frequently than BRT and LRT. As Hovee quips, "If light rail systems function as highways and arterials, streetcar systems function as the local streets" (8). They also tend to be found in downtowns, the only notable exception being Portland's extension of its downtown streetcar looping across the Willamette River.

It is against this backdrop that our study addresses the question of whether streetcars promote economic development, measured by employment change. It is the first comparative study of employment patterns associated with modern streetcars in the United States, examining 
four modern streetcar systems that had completed construction and initiated service at the time of this study.

\section{Methodology}

Economic development may be assessed in various ways. In the literature on transportation and land use there are three common metrics. One approach measures economic development in terms of financial investment in real estate development ( 6 ), another as changes in real estate value $(10)$, and a third in terms of employment $(9,11)$. It is difficult in any case to make a direct causal link between a transportation project and the real estate development metric; the relationship is generally inferred by examining spatial patterns and temporal trends in the data. A further challenge is presented in studies that compare more than one city, because local data associated with real estate development, building permits, etc., are collected and maintained locally and in different ways from one jurisdiction to the next. Thus no objective, comparative, multi-city studies of economic development associated with streetcar projects have been completed to date.

In order to avoid the challenges of obtaining comparable real estate investment data for all four cities in our study, employment was chosen to be the metric for economic development. This metric has the advantage of being available nationwide in a common format (US Census). However, it has the arguable disadvantage of being perhaps less responsive to streetcar development in the sense that real estate investment generally must occur first, in order for the employment to follow. For this reason, and because the streetcar lines in question are so new, this analysis can only lay the groundwork for detecting employment change for the new lines 
studied in this paper. The processes of change taking place may well be far from having run their course and only show small indications of things to come.

From a city planning perspective, forward-looking investments in public transit such as light rail are expected to increase density (residential and/or employment) near transit stations, as rail infrastructure is too expensive to cost-efficiently serve low density land uses. There are complications in studying the impacts of rail transit investment, however, because changes in density associated with rail transit projects may either reflect new, net economic growth occurring preferentially in those locations, or it may reflect spatial redistribution of pre-existing jobs. In addition, there is a chicken-or-egg dilemma in assessing economic impacts, as many transit investments are intentionally located to serve already-dense or growing population or job centers (see 11 for trends in California). That is, transit projects may be built specifically in locations that are already on a growth trajectory.

In this project, four streetcar systems were studied that were new streetcars, not "heritage" lines, carrying modern trains and developed primarily to serve transit functions for the local community rather than tourists. The four study systems were Portland, Oregon's Central Loop; Salt Lake City, Utah's S Line; Seattle, Washington's South Lake Union line; and New Orleans, Louisiana's Rampart-St. Claude Line. Changes in employment around focal streetcar stops were tracked over time against a set of comparable non-streetcar control sites, with the Central County as a whole ${ }^{1}$, and within economic groups. For each study system, a "before" year, specified as 3 years prior to the beginning of construction, and an "after" year, specified as 2013, being the most recent year for which data were available, were determined (see Appendix

1 We use central counties for our region because streetcar systems are designed to serve only the most centralized and built out area of the central county. 
for dates). The before date was considered to reflect the date of the project funding announcement, since such an announcement might trigger real estate speculation, however since only employment is being studied, not real estate investment or land values, the date of three years prior to the construction start was considered sufficiently early as to represent a "before" condition. The after dates are the primary limitation of this study: service on two of these streetcar systems began so recently (Salt Lake City: 08 December 2013²; New Orleans: 28 January $2013^{3}$ ) that the most recent available data at the time of this study are less than one year after start of service.

\section{Study locations and controls}

For each streetcar line studied, three focal stops were selected to serve as experimental "treatments". The primary selection criterion for streetcar stops was spacing, that they be far enough apart that quarter-mile buffers around each stop would not overlap significantly with one another and that they represent as much of the full length of the line as possible. Each treatment site consists of a quarter-mile radius walkshed centered on the selected stop. Guerra, Cervero and Tischer (15) find support for a quarter mile catchment as appropriate for employment-transit studies. Each walkshed had a different socioeconomic profile and in order to detect the effect of streetcar development, a set of control sites with similar profiles but without streetcars, were selected for comparison. A multidimensional similarity measure was used to select 10 control sites for comparison with each study stop; these control sites were located within the same metropolitan area, were served by existing bus routes, and shared similar socioeconomic

\footnotetext{
${ }^{2}$ https://en.wikipedia.org/wiki/S_Line_(Utah_Transit_Authority); accessed 03 March 2016 ${ }^{3}$ https://en.wikipedia.org/wiki/Rampart-St._Claude_Streetcar_Line; accessed 03 March 2016 
characteristics in terms of population, employment, housing units, households, median household income as reported at the Census block group level prior to the streetcar project development's before date. A similar conceptual approach, with slightly different methodology, may be found in Kolko's analysis (11). The process of selecting control station areas consisted of two steps: first, creating a large set of candidate points, and second, assessing each candidate point for similarity with the actual streetcar locations. For the first step, it was assumed that bus service follows corridors that are similar to those considered by planners when designing streetcar alignments, and a large number of points $(\mathrm{n}=1000)$ randomly distributed along the network of arterial streets was created.

The second step used census measures of population, employment, housing units, households, and median household income at the Census block group level from the identified "before" year. These variables were chosen because of their availability at annual intervals going back to the earliest year considered in our study (2003 for the Seattle line) and their universal availability from US Census; the block group is dictated as the spatial unit of reporting as this is the finest unit for which the Census Bureau reports the median household income variable.

For each streetcar station (treatment) point and candidate control station point, values were estimated for each of the five variables for the area within one-quarter mile of the point, allocating block group level measures proportionately to the fraction of the block group falling within this area. The distributions of the five measures were checked for normality and, if necessary, transformed to normalize them; individual measures were then standardized to zscores. Taking each streetcar station (treatment) point individually, the distance in the standardized 5-dimensional space was computed between the treatment point and each candidate control point. This distance is proportionate to dissimilarity, and the final ten control sites were 
selected starting with the smallest dissimilarity distances from each streetcar station (treatment) sites and rejecting candidates that overlapped in geographic space with already-selected control sites.

\section{Descriptive Analysis}

Each system was evaluated for the change in overall employment and employment in economic groups over the study periods. The streetcar station areas and the central county were compared, as well as control station areas with the central county; in both cases using z-scores to test whether differences over time are statistically different from null. While we did not analyze the impact of planning policies associated with each streetcar project, these policies are listed in the Appendix.

\section{Employment Analysis}

With this study design, employment within each treatment walkshed is compared with itself over time (before-after), and with its respective set of control walksheds, also over time. In addition, as in the BRT study by Nelson et al (9), shift-share analysis was used to examine employment trends at each of the study sites and controls. This approach looks at employment within each walkshed at the before and after dates, compared with broader trends in the central county as a whole, and within industry sectors in the central county, and allows the determination of changes in employment at each studied treatment or control site as attributable to broader trends within the central county (as a whole and/or within industry sectors) or as due to local factors at the study site. Nelson et al. (9) developed the shift-share approach for transitrelated economic development that was used in this study. 
Longitudinal Employer Household Dynamics (LEHD) data from the US Census Bureau was used for the before and after years at the Census Block and Central County levels. LEHD economic sectors were combined into economic groups reflecting roughly comparable employment, land use, and building characteristics (see 16 for details). Economic sectors were not included for which workers do not occupy building spaces on a regular basis, such as farming, forestry, fishing, mining and construction.

\section{Application and Results}

The results are presented for each streetcar line in the following format: 1) overview of the system history and focal station areas; 2) employment change for the streetcar station areas and for the Central County as a whole with individual sector assessments; and 3) apportionment of shift-share results with respect to control station areas and station areas. At the end of the section, the results are broadly summarized in Table 5 for comparative purposes. In addition, all four cities enacted zoning adjustments to facilitate development along the new streetcar corridors. Although we did not analyze the impacts of these policies, they are listed for reference in the Appendix.

\section{Portland, OR - Central Loop Line}

The Portland Phase II streetcar system, known as the Loop, opened in 2012, although elements of the system, such as the Tilikum Crossing Bridge, were not operational until September 2015. As discussed previously, the first phase of Portland's streetcar system, the North-South Line, opened in 2001 and represented the first modern streetcar project in the 
United States. The success of Phase I in stimulating economic development has already been explored, so the Loop portion was the focus of the current research. The Central Loop line was chosen because 1) it serves an area outside of, and across the Willamette River from, downtown and 2) the original North-South line has already been studied. Land use policies were put in place around the line, as described in the Portland Comprehensive Plan, to support development around, and the use of, the streetcar. The policies describe the potential use of transit investments, support of economic development goals with transportation planning, and rezoning permitted uses and density maximums to further foster economic growth. The Portland stations were all located along the "B Loop" and include these stations:

- Northeast Grand at Holladay

- Grand and Stark

- Southeast Grand and Hawthorne.

For brevity, results are reported for the combination of treatment and control sites. Table 1 reports descriptive results as well as shift-share results, focusing only on the control station area and streetcar station area effects. Discussion follows. 
Overall, the control areas increased jobs by 6 percent during the study period while the central county (Multnomah) grew by 8 percent, which is not a significant difference in change based on $\mathrm{z}$ scores. In contrast, the streetcar station areas added 22 percent to their cumulative job base between 2006 and 2013, which is significant. Shift-share analysis shows that whereas control areas lost share of change in jobs during the study period, streetcar station areas gained shared. Cumulatively, both streetcar station areas and controls had statistically significant gains in jobs in several economic groups though the control areas lost jobs in the light industrial and retail-lodging-food groups. Education and health care economic groups added significant numbers of jobs in the control areas while the streetcar station areas did not. On the whole, streetcar station areas performed better during the study period in attracting jobs in more economic groups than the controls.

It is clear that the employment mix differs among streetcar station areas, and among control areas as well as between the streetcar station areas and their matched control station controls. The three consistent employment growth areas for streetcar stations in Portland were Knowledge, Retail-Lodging-Food, and Health. 


\section{Salt Lake City, UT - S Line}

The S Line is the first modern streetcar line in Utah. It joins the main TRAX light rail system at its western end, and runs east for two miles through a dedicated right-of-way that previously carried freight rail, ending in Salt Lake City's “second downtown," the Sugar House neighborhood. Future planned phases would extend the line deeper into Sugar House and eventually create a loop, connecting back to the TRAX Red Line, however no funding has yet been secured for future phases. The line was built rapidly, with construction initiated in April 2012 and the opening of the line in December 2013. Redevelopment activity along the line has been quite variable, with high levels of investment in the Sugar House area and less at other locations. A form-based code was put in place around the streetcar line to support redevelopment activity. The form-based code allows a variety of land uses and building types that increase economic potential along the line. Streetcar stations used in the analysis include:

- Fairmont Station;

- 500 East Station

- South Salt Lake Station.

The S Line is unique in several ways. In addition to running through an abandoned rail corridor instead of in a street, the project also includes a linear park and bike path that represents a critical linkage in the regional bicycle system. Moreover, the South Salt Lake Station is substantially surrounded by a park-and-ride lot serving the TRAX light rail system. With the exception of the Sugar House end of the line, the areas served by the S Line were not on a growth or redevelopment trajectory prior to the construction of the streetcar. Table 2 reports pooled descriptive and shift-share results for streetcar station areas and control areas, and for Salt Lake County as a whole. 
During the study period - extending from the depths of the Great Recession well into recovery-jobs increased by 25 percent in the control station areas but decreased by 2 percent in the streetcar station areas, both significant relative to the Salt Lake central county increase of 7 percent. Shift-share analysis further shows that by controlling for regional and industrial mix influences, the control station areas gained share of jobs while streetcar station areas lost share. The control areas gained jobs in most economic groups, notably retail-lodging-food. In contrast, the streetcar station areas lost jobs in many more groups than they gained, though they did gain substantially more and statistically significant jobs in the office economic group.

When considered separately, there is no consistency among streetcar stations in Salt Lake with regard to employment sector dynamics. What growth there is at streetcar stations is driven primarily by growth at the Sugar House end of the line, although there is some office growth at South Salt Lake. The 500 E station area experienced a hemorrhaging of jobs over the study time period.

Short-term economic development outcomes of the S Line should not be surprising. Not only does the line not travel along a regular street but a key station (South Salt Lake) is mostly a park-and-ride lot. Much of the length of the line is also currently dominated by relatively lowdensity and low-to-moderate-income single-family housing that is unlikely to redevelop in the near future. This project was built opportunistically, with a view to the long-term infrastructure of the city, not as a local economic development stimulus. The economic growth that has occurred around the Sugar House terminus is in a regional center that was poised to take off regardless of the addition of a new rail-transit line. 


\section{Seattle, Washington - South Lake Union Streetcar}

The South Lake Union Streetcar in Seattle started operation in 2007, connecting the South Lake Union neighborhood to downtown. The neighborhood was approved to be developed as a biotechnology and biomedical research center and those sectors contributed heavy funding for the streetcar. In 2010, Amazon built a new campus building in South Lake Union, which increased ridership considerably. The area is substantially developed into offices and other nonresidential uses though new high-density residential development has dominated new construction on parking lots and the redevelopment of older, low-rise structures. All of the development occurred after rezoning the area from industrial to land uses that would create a productive urban center. The effect of the change in policies was major redevelopment, economic growth, and a willingness on the part of developers to invest in projects around the streetcar line. The streetcar stations evaluated include the following:

- Westlake Hub

- Westlake Ave and Thomas Street

- Fairview Ave and Campus Drive.

What follows is a discussion of the key interpretations of Table 3 which reports descriptive and shift-share results.

Spanning 10 years, this line's before/after study period was the longest of the cases evaluated. Unlike Portland, the Seattle streetcar system has not been expanded beyond its small downtown footprint. As seen in Table 3, it has also not performed well relative to the central county. During the study period,the control station areas increased jobs by 27 percent whereas King County's increased by 15 percent, and streetcar station areas actually lost one percent of 
jobs, mostly in the office sector group. Otherwise, statistically significant changes among economic groups around streetcar stations were positive. During much of the study period and especially since the Great Recession, residential development in downtown Seattle has outstripped office and other nonresidential development. Results shown in Table 3 confirm this. The effect of residential development near streetcar stations should be the subject of future research.

Shift-share analysis shows that whereas control station areas gained share of jobs overall, streetcar station areas lost share. Indeed, streetcar station areas lost share of jobs in six of eight economic groups compared to just one for the control station areas. Health and ArtsEntertainment-Recreation appear to be the most consistent positive growth sectors for streetcar station areas but again, there is little consistency between locations. 


\section{New Orleans, LA - Rampart-St. Claude Line}

New Orleans' Rampart-St. Claude Streetcar line opened in 2013, one of the newest systems in this study. It begins at a transit hub that connects Amtrak, Greyhound and Regional Transit Authority (RTA) bus lines, and runs 0.8 miles into the New Orleans Central Business District, running through the historic arts and theater district. The streetcar station areas are:

- Union Passenger Terminal

- Rampart-St. Claude Ave and Poydras Street

- Canal Street and Elk

As this is the newest system studied, there may not have been enough time for the market to respond to the streetcar system. Land use policies were established to help with economic development, such as rezoning with overlays that support mixed use and multi modal and aim for 24 hour programming. On the other hand, among all the systems, this may be the one with the most advance planning. Construction and initiation of service on this line follows a sustained wave of recovery-related growth for Orleans Parish (the central county) initially from Hurricane Katrina and then the Great Recession. Finally, it is in an area dominated by surface parking lots and older properties, prime for redevelopment. Table 4 reports economic development outcomes for the streetcar and control station areas. 
Table 4 shows that overall, the streetcar station areas outperformed Orleans Parish and the control areas, gaining jobs at 17 percent compared to the Parish at seven percent while the control areas lost three percent. Moreover, where the control areas lost jobs in six of the eight economic groups, the streetcar station areas lost jobs in just three. The shift-share results show further that the streetcar station areas gained share of central county jobs overall while the control areas lost job share.

Overall, relative to their matched controls, the streetcar station areas are all clearly more dynamic with regard to employment than control areas in New Orleans, however the dynamism does not follow consistent trends across station areas. The only consistent growth areas for streetcar station areas were Office and Retail-Lodging-Food. 


\section{Interpretations and Implications}

The primary outcome desired from these analyses is consistency in the response of employment to streetcars. Does each city streetcar line behave in an internally consistent manner, or is the difference between station areas greater than the difference between cities? If local employment effects are consistent among the sites within a single streetcar line, and in their differences with control sites, it is likely that there is a streetcar effect for that city. If streetcars may be said to reliably promote economic development (as measured here by employment), then there should be: 1) across all sites and cities, a greater positive change in employment at treatment sites than at controls and 2) positive local effects in the shift-share results. It should be noted that all four cities enacted zoning changes and design standards that facilitated development along the streetcar corridor, including mixed-use, transit-oriented development, and increased permitted densities (Appendix).

Among the study streetcar lines, Portland's Central Loop line exhibits by far the greatest internal consistency in employment response. As expected, there is positive employment growth among the streetcar station areas that exceeds the growth at control sites. There is an economic development pattern that extends the pattern established with the original Portland North-South streetcar line. This confirms that Portland has an established streetcar-economic development strategy that works for Portland. The city and its business community have "bought in" to the streetcar paradigm and effective planning and design have created a streetcar system that functions well in both its transportation and economic functions. While the raw scale and industry mix of employment varies from one station to the next, the results of the analysis reflect heavy economic development and job growth locating preferentially at streetcar stations, well 
ahead of control areas and the metropolitan area as a whole, even though the Loop line only became fully connected in 2015 .

Of the other streetcars included in this study, it might be predicted that Seattle would be the most likely to follow the Portland model. Both are Pacific Northwest cities with similar culture and feel, although Seattle is much larger. Seattle's streetcar has also been in operation longer than any of the other lines considered in this study, second only to the original Portland line. However, this prediction was not borne out in analysis. Certainly, considerable investment in real estate redevelopment by major employers such as Amazon has occurred within and near the streetcar station areas, but job performance has been surprisingly weak, actually declining. The Seattle example is lacking the internal consistency that was expected, showing patchy development along the streetcar line. However, it is also known from current ongoing work that whereas job production may be weak, residential development has dominated the streetcar station areas since the Great Recession.

The New Orleans streetcar was built within the unique context of recovery from Hurricane Katrina. As noted by Guthrie and Fan (6), there has been significant commercial investment along the streetcar line during the post-Katrina years, but this has occurred within the context of strong investment and recovery activities citywide. New Orleans also has a long history of streetcars, making it more likely that investors will feel comfortable with streetcars as a valuable amenity. In fact, all three streetcar stations in this study showed positive employment growth and out-performed the control sites in both direct comparison and shift-share analysis. Furthermore, it is evident that all of the streetcar sites in New Orleans are more dynamic than their matched controls. Can streetcar sites in New Orleans become the centers of focused 
development that we have seen in Portland? This is left to future research, but there is certainly strong potential.

The streetcar with perhaps the least internal consistency is the S Line serving the Sugar House area of Salt Lake City. The streetcar concept is new to Salt Lake City (although it had a streetcar network in the past), and the corridor through which the S Line runs is in the early stages of what will probably be decades of change. Wildly differing and rapidly changing employment numbers along the line indicate possibly several processes at work: relocation of jobs and activities along the corridor, vacating of older buildings and businesses in preparation for demolition, redevelopment, renovation, and simply very different uses of land and land densities at the different stops. Furthermore, the S Line does not run within a street, but through its own right of way that also supports a linear park, bike trail, and easy pedestrian movement. It is a novel and unique amenity, and it still remains to be seen how employment activities might orient themselves in relation to it. Among all streetcar lines studied and perhaps even all such lines nationally, the S Line's design may be the most unique, though also, potentially, least conducive to stimulating economic development.

Overall, Portland has continued to follow in its own footsteps as this analysis confirms previous observations of Portland's streetcar success story. All of the other cities lacked the consistency of Portland. As the literature review above showed, Portland's streetcar itself is only part of a mosaic of planning and development policies designed to reinforce streetcar use. Our policy inventory (Appendix) indicated that all four cities did implement zoning changes to facilitate development along the streetcar line. It seems likely that in the case of the newer systems, employment development will follow, eventually, as there is evidence of employment change occurring. Portland may have been in a better position to develop quickly, based on its 
recent experience with the earlier streetcar line. Our study also did not have a way to gauge the degree of buy-in on the part of the local business community and the dynamics of public-private sector relationships in each city. A final point is that despite the short distance between streetcar stations, from the perspective of supporting business development and therefore employment growth, a streetcar line does not behave as a corridor but as a series of discrete points associated with individual station areas.

\section{References}

1. Sullivan, P. and Olivo, A. 2014-11-18. Arlington officials halt efforts on long-planned streetcar projects for Columbia Pike, Crystal City. Washington Post.

2. O’Toole, R. 2012. The Great Streetcar Conspiracy. Cato Institute Policy Analysis no. 699.

3. The Economist. August 9, 2014. Streetcars and Urban Renewal: Rolling Blunder. http://www.economist.com/news/united-states/21611123-federal-subsidies-haveinspired-some-silly-transit-projects-rolling-blunder

4. Brown, J., H. Nixon, and E. Ramos. 2015. The Purpose, Function, and Performance of Streetcar Transit in the Modern U.S. City: A Multiple-Case-Study Investigation. Mineta Transportation Institute Report 12-39.

5. Marshall, S. 2015. Streetcars of desire: why are American cities obsessed with building streetcars? The Guardian. Friday February 20, 2015. http://www.theguardian.com/cities/2015/feb/20/streetcars-of-desire-why-are-americansobsessed-with-building-trams accessed Dec.10,2015. 
6. Guthrie, A. and Y. Fan. 2013. Streetcars and Recovery: an analysis of post-Katrina building permits around New Orleans streetcar lines. Journal of Planning Education and Research 33(4): 381-394.

7. Hovee, E.D. and R. Gustafson. 2012. Streetcar-Development Linkage: The Portland Streetcar Loop. Transportation Research Board conference publication. http://onlinepubs.trb.org/onlinepubs/conferences/2012/LRT/RGustafson.pdf

8. Hovee, E.D. 2008. Streetcar-Development Linkage: The Portland Streetcar Loop. E.D. Hovee \& Company, LLC, prepared for City of Portland Office of Transportation.

9. Nelson, A.C., G. Anderson, K. Bartholomew, P. Perlich, T.W. Sanchez, and R. Ewing. 2009. The Best Stimulus for the Money: Briefing Papers on the Economics of Transportation Spending. Smart Growth America http://www.smartgrowthamerica.org/documents/thebeststimulus.pdf

10. Higgins, C. D. and P.S. Kanaroglou. 2015. 40 Years of Modelling Rail Transit's Land Value Uplift in North America: Diverse Methods, Differentiated Outcomes, Debatable Assumptions, and Future Directions. Transportation Research Board Annual Meeting 2015 Paper \#15-4103.

11. Kolko, J. 2011. Making the Most of Transit: Density, Employment Growth, and Ridership Around New Stations. Public Policy Institute of California http://www.ppic.org/main/publication.asp?i=947

12. Mokadi, E., D. Mitsova, and X. Wang. 2013. Projecting the impacts of a proposed streetcar system on the urban core land redevelopment: The case of Cincinnati, Ohio. Cities 35: 136-146.

13. Nelson, A. C., R. Ewing, M. Miller, S. Kannan, B. Appleyard. 2013. Bus Rapid Transit 
and Economic Development. Journal of Public Transportation. 16(3): 41-57.

14. Belzer, D., S. Srivastava, and M. Austin. 2011. Transit and Regional Economic Development. Oakland, CA: Center for Transit-Oriented Development. http://www.reconnectingamerica.org/resource-center/browse-research/2011/transit-andregional-economic-development/

15. Guerra, E., R. Cervero and D. Tischler. 2011. The Half-Mile Circle: Does it Best Represent Transit Station Catchments? University of California Transportation Center UCTC-FR-2011-09.

16. Hinners, S. J. and M. A. Larice. 2016. Assessing the Impacts of Streetcars on Economics, Equity, and Quality of Life. Salt Lake City, Utah: Metropolitan Research Center, University of Utah available at http://mrc.cap.utah.edu/wpcontent/uploads/sites/8/2015/12/Assessing-the-Impacts-of-Streetcars-on-EconomicsEquity-and-Quality-of-Life-HUD-Sustainable-Communities-Grant-Deliverable-August2016.pdf 
Table 1

Pooled Descriptive and Shift-Share Results for Portland Streetcar Economic Development Analysis.

\begin{tabular}{|c|c|c|c|c|c|c|c|}
\hline & $\begin{array}{r}\text { Control } \\
\text { Station Area }\end{array}$ & $\begin{array}{r}\text { Control } \\
\text { Station Area }\end{array}$ & Central & Central & $\begin{array}{r}\text { Control } \\
\text { Station Area }\end{array}$ & $\begin{array}{l}\text { Central } \\
\text { County }\end{array}$ & Control Station \\
\hline Economic Group & 2006 & 2013 & County 2006 & County 2013 & Change & Change $z$ & Area Share \\
\hline Manufacturing & 29 & 54 & 40,166 & 36,988 & $86 \%$ & $-8 \% *$ & 27 \\
\hline Light Industrial & 310 & 166 & 28,403 & 26,919 & $-46 \%$ & $-5 \% *$ & $(128)$ \\
\hline Retail-Lodging-Food & 3,490 & 3,402 & 90,257 & 97,573 & $-3 \%$ & $8 \% *$ & (371) \\
\hline Knowledge & 687 & 750 & 58,714 & 70,044 & $9 \%$ & $19 \%$ & (70) \\
\hline Office & 2,365 & 2,818 & 164,032 & 172,446 & $19 \%$ & $5 \% *$ & 332 \\
\hline Education & 126 & 200 & 19,002 & 23,652 & $59 \%$ & $24 \% *$ & 43 \\
\hline Health & 5,210 & 5,605 & 60,270 & 68,912 & $8 \%$ & $14 \% *$ & (352) \\
\hline Arts-Ent-Rec & 242 & 271 & 15,432 & 18,482 & $12 \%$ & $20 \%$ & (19) \\
\hline \multirow[t]{2}{*}{ Total } & 12,459 & 13,266 & 476,276 & 515,016 & $6 \%$ & $8 \%$ & $(537)$ \\
\hline & $\begin{array}{r}\text { Streetcar } \\
\text { Station Area } \\
2006\end{array}$ & $\begin{array}{r}\text { Streetcar } \\
\text { Station Area } \\
2013\end{array}$ & $\begin{array}{r}\text { Central } \\
\text { County } 2006\end{array}$ & $\begin{array}{r}\text { Central } \\
\text { County } 2013\end{array}$ & $\begin{array}{r}\text { Streetcar } \\
\text { Station Area } \\
\text { Change }\end{array}$ & $\begin{array}{l}\text { Central } \\
\text { County } \\
\text { Change z }\end{array}$ & $\begin{array}{r}\text { Streetcar } \\
\text { Station Area } \\
\text { Share }\end{array}$ \\
\hline Manufacturing & 863 & 904 & 40,166 & 36,988 & $5 \%$ & $-8 \% *$ & 109 \\
\hline Light Industrial & 1,767 & 2,017 & 28,403 & 26,919 & $14 \%$ & $-5 \% *$ & 342 \\
\hline Retail-Lodging-Food & 2,038 & 2,522 & 90,257 & 97,573 & $24 \%$ & $8 \% *$ & 319 \\
\hline Knowledge & 958 & 1,736 & 58,714 & 70,044 & $81 \%$ & $19 \% *$ & 593 \\
\hline Office & 5,978 & 7,052 & 164,032 & 172,446 & $18 \%$ & $5 \% *$ & 767 \\
\hline Education & 76 & 106 & 19,002 & 23,652 & $39 \%$ & $24 \%$ & 11 \\
\hline Health & 878 & 1,070 & 60,270 & 68,912 & $22 \%$ & $14 \%$ & 66 \\
\hline Arts-Ent-Rec & 173 & 188 & 15,432 & 18,482 & $9 \%$ & $20 \%$ & (19) \\
\hline Total & 12,731 & 15,595 & 476,276 & 515,016 & $22 \%$ & $8 \% *$ & 2,189 \\
\hline
\end{tabular}


Table 2

Pooled Descriptive and Shift-Share Results for Salt Lake City Streetcar Economic Development Analysis

\begin{tabular}{|c|c|c|c|c|c|c|c|}
\hline Economic Group & $\begin{array}{r}\text { Control } \\
\text { Station Area } \\
2009\end{array}$ & $\begin{array}{r}\text { Control } \\
\text { Station Area } \\
2013\end{array}$ & $\begin{array}{r}\text { Central } \\
\text { County } 2009\end{array}$ & $\begin{array}{r}\text { Central } \\
\text { County } 2013\end{array}$ & $\begin{array}{r}\text { Control } \\
\text { Station Area } \\
\text { Change }\end{array}$ & $\begin{array}{l}\text { Central } \\
\text { County } \\
\text { Change z }\end{array}$ & $\begin{array}{r}\text { Control } \\
\text { Station Area } \\
\text { Share }\end{array}$ \\
\hline Manufacturing & 79 & 108 & 52,503 & 54,956 & $37 \%$ & $5 \% *$ & 25 \\
\hline Light Industrial & 32 & 20 & 33,170 & 34,713 & $-38 \%$ & $5 \% *$ & (13) \\
\hline Retail-Lodging-Food & 753 & 1,404 & 117,648 & 125,702 & $86 \%$ & $7 \% *$ & 599 \\
\hline Knowledge & 267 & 230 & 71,808 & 81,006 & $-14 \%$ & $13 \% *$ & (71) \\
\hline Office & 445 & 507 & 242,008 & 254,659 & $14 \%$ & $5 \%$ & 39 \\
\hline Education & 195 & 200 & 17,421 & 21,496 & $3 \%$ & $23 \% *$ & (41) \\
\hline Health & 935 & 950 & 60,907 & 65,460 & $2 \%$ & $7 \%$ & (55) \\
\hline Arts-Ent-Rec & 92 & 70 & 13,757 & 14,420 & $-24 \%$ & $5 \% *$ & (26) \\
\hline Total & 2,798 & 3,489 & 609,222 & 652,412 & $25 \%$ & $7 \% *$ & 457 \\
\hline Economic Group & $\begin{array}{r}\text { Streetcar } \\
\text { Station Area } \\
2009\end{array}$ & $\begin{array}{r}\text { Streetcar } \\
\text { Station Area } \\
2013\end{array}$ & $\begin{array}{r}\text { Central } \\
\text { County } 2009\end{array}$ & $\begin{array}{r}\text { Central } \\
\text { County } 2013\end{array}$ & $\begin{array}{r}\text { Streetcar } \\
\text { Station Area } \\
\text { Change }\end{array}$ & $\begin{array}{l}\text { Central } \\
\text { County } \\
\text { Change z }\end{array}$ & $\begin{array}{r}\text { Streetcar } \\
\text { Station Area } \\
\text { Share }\end{array}$ \\
\hline Manufacturing & 402 & 141 & 52,503 & 54,956 & $-65 \%$ & $5 \% *$ & $(280)$ \\
\hline Light Industrial & 285 & 207 & 33,170 & 34,713 & $-27 \%$ & $5 \% *$ & (91) \\
\hline Retail-Lodging-Food & 1,441 & 1,492 & 117,648 & 125,702 & $4 \%$ & $7 \%$ & (48) \\
\hline Knowledge & 338 & 361 & 71,808 & 81,006 & $7 \%$ & $13 \%$ & (20) \\
\hline Office & 1,376 & 1,563 & 242,008 & 254,659 & $14 \%$ & $5 \% *$ & 115 \\
\hline Education & 91 & 64 & 17,421 & 21,496 & $-30 \%$ & $23 \% *$ & (48) \\
\hline Health & 75 & 101 & 60,907 & 65,460 & $35 \%$ & $7 \% *$ & 20 \\
\hline Arts-Ent-Rec & 81 & 92 & 13,757 & 14,420 & $14 \%$ & $5 \%$ & 7 \\
\hline Total & 4,089 & 4,021 & 609,222 & 652,412 & $-2 \%$ & $7 \% *$ & (345) \\
\hline
\end{tabular}


Table 3

Descriptive and Shift-Share Results for Seattle Streetcar Economic Development Analysis

\begin{tabular}{|c|c|c|c|c|c|c|c|}
\hline Economic Group & $\begin{array}{r}\text { Control } \\
\text { Station Area } \\
2003\end{array}$ & $\begin{array}{r}\text { Control } \\
\text { Station Area } \\
2013\end{array}$ & $\begin{array}{r}\text { Central } \\
\text { County } 2003\end{array}$ & $\begin{array}{r}\text { Central } \\
\text { County } 2013\end{array}$ & $\begin{array}{r}\text { Control } \\
\text { Station Area } \\
\text { Change }\end{array}$ & $\begin{array}{l}\text { Central } \\
\text { County } \\
\text { Change z }\end{array}$ & $\begin{array}{r}\text { Control } \\
\text { Station Area } \\
\text { Share }\end{array}$ \\
\hline Manufacturing & 508 & 624 & 112,737 & 112,807 & $23 \%$ & $0 \% *$ & 116 \\
\hline Light Industrial & 8,850 & 9,041 & 68,725 & 68,425 & $2 \%$ & $-0 \% *$ & 230 \\
\hline Retail-Lodging-Food & 7,139 & 8,155 & 223,327 & 246,110 & $14 \%$ & $10 \% *$ & 288 \\
\hline Knowledge & 18,553 & 24,263 & 194,368 & 254,175 & $31 \%$ & $31 \%$ & 1 \\
\hline Office & 38,163 & 51,432 & 386,941 & 419,973 & $35 \%$ & $9 \% *$ & 10,011 \\
\hline Education & 7,666 & 8,291 & 27,731 & 36,057 & $8 \%$ & $30 \% *$ & $(1,677)$ \\
\hline Health & 1,283 & 2,458 & 114,410 & 159,481 & $92 \%$ & $39 \% *$ & 670 \\
\hline Arts-Ent-Rec & 1,363 & 1,517 & 36,577 & 44,137 & $11 \%$ & $21 \% *$ & (128) \\
\hline \multirow[t]{2}{*}{ Total } & 83,525 & 105,781 & $1,164,816$ & $1,341,165$ & $27 \%$ & $15 \% *$ & 9,511 \\
\hline & $\begin{array}{r}\text { Streetcar } \\
\text { Station Area } \\
2003\end{array}$ & $\begin{array}{r}\text { Streetcar } \\
\text { Station Area } \\
2013\end{array}$ & $\begin{array}{r}\text { Central } \\
\text { County } 2003\end{array}$ & $\begin{array}{r}\text { Central } \\
\text { County } 2013\end{array}$ & $\begin{array}{r}\text { Streetcar } \\
\text { Station Area } \\
\text { Change }\end{array}$ & $\begin{array}{l}\text { Central } \\
\text { County } \\
\text { Change z }\end{array}$ & $\begin{array}{r}\text { Streetcar } \\
\text { Station Area } \\
\text { Share }\end{array}$ \\
\hline Manufacturing & 751 & 396 & 112,737 & 112,807 & $-47 \%$ & $0 \%$ & (355) \\
\hline Light Industrial & 7,874 & 7,824 & 68,725 & 68,425 & $-1 \%$ & $-0 \%$ & (16) \\
\hline Retail-Lodging-Food & 10,227 & 10,491 & 223,327 & 246,110 & $3 \%$ & $10 \% *$ & (779) \\
\hline Knowledge & 15,521 & 18,356 & 194,368 & 254,175 & $18 \%$ & $31 \% *$ & $(1,941)$ \\
\hline Office & 22,032 & 15,358 & 386,941 & 419,973 & $-30 \%$ & $9 \% *$ & $(8,555)$ \\
\hline Education & 609 & 818 & 27,731 & 36,057 & $34 \%$ & $30 \%$ & 26 \\
\hline Health & 2,281 & 4,633 & 114,410 & 159,481 & $103 \%$ & $39 \% *$ & 1,453 \\
\hline Arts-Ent-Rec & 858 & 1,805 & 36,577 & 44,137 & $110 \%$ & $21 \% *$ & 770 \\
\hline $\begin{array}{l}\text { Total } \\
* Z \text { scores are } p<0.05\end{array}$ & 60,153 & 59,681 & $1,164,816$ & $1,341,165$ & $-1 \%$ & $15 \% *$ & $(9,397)$ \\
\hline
\end{tabular}


Table 4

Descriptive and Shift-Share Results for New Orleans Streetcar Economic Development Analysis

\begin{tabular}{|c|c|c|c|c|c|c|c|}
\hline Economic Group & $\begin{array}{r}\text { Control } \\
\text { Station Area } \\
2008\end{array}$ & $\begin{array}{r}\text { Control } \\
\text { Station Area } \\
2013\end{array}$ & $\begin{array}{r}\text { Central } \\
\text { County } 2008\end{array}$ & $\begin{array}{r}\text { Central } \\
\text { County } 2013\end{array}$ & $\begin{array}{r}\text { Control } \\
\text { Station Area } \\
\text { Change }\end{array}$ & $\begin{array}{l}\text { Central } \\
\text { County } \\
\text { Change z }\end{array}$ & $\begin{array}{r}\text { Control } \\
\text { Station Area } \\
\text { Share }\end{array}$ \\
\hline Manufacturing & 313 & 116 & 6,970 & 4,766 & $-63 \%$ & $-32 \% *$ & (98) \\
\hline Light Industrial & 1,212 & 882 & 5,707 & 4,904 & $-27 \%$ & $-14 \% *$ & $(160)$ \\
\hline Retail-Lodging-Food & 5,256 & 5,149 & 41,972 & 53,293 & $-2 \%$ & $27 \% *$ & $(1,524)$ \\
\hline Knowledge & 3,559 & 3,424 & 25,205 & 28,858 & $-4 \%$ & $14 \% *$ & $(652)$ \\
\hline Office & 4,036 & 4,571 & 77,590 & 77,023 & $13 \%$ & $-1 \% *$ & 565 \\
\hline Education & 53 & 84 & 15,249 & 19,540 & $58 \%$ & $28 \%$ & 16 \\
\hline Health & 253 & 176 & 18,591 & 21,868 & $-30 \%$ & $18 \% *$ & $(122)$ \\
\hline Arts-Ent-Rec & 205 & 84 & 9,534 & 9,627 & $-59 \%$ & $1 \% *$ & $(123)$ \\
\hline \multirow[t]{2}{*}{ Total } & 14,887 & 14,485 & 200,818 & 219,879 & $-3 \%$ & $9 \% *$ & $(2,098)$ \\
\hline & $\begin{array}{r}\text { Streetcar } \\
\text { Station Area } \\
2008\end{array}$ & $\begin{array}{r}\text { Streetcar } \\
\text { Station Area } \\
2013\end{array}$ & $\begin{array}{r}\text { Central } \\
\text { County } 2008\end{array}$ & $\begin{array}{r}\text { Central } \\
\text { County } 2013\end{array}$ & $\begin{array}{r}\text { Streetcar } \\
\text { Station Area } \\
\text { Change }\end{array}$ & $\begin{array}{l}\text { Central } \\
\text { County } \\
\text { Change z }\end{array}$ & $\begin{array}{r}\text { Streetcar } \\
\text { Station Area } \\
\text { Share }\end{array}$ \\
\hline Manufacturing & 121 & 97 & 6,970 & 4,766 & $-20 \%$ & $-32 \%$ & 14 \\
\hline Light Industrial & 603 & 432 & 5,707 & 4,904 & $-28 \%$ & $-14 \% *$ & $(86)$ \\
\hline Retail-Lodging-Food & 3,744 & 7,309 & 41,972 & 53,293 & $95 \%$ & $27 \% *$ & 2,555 \\
\hline Knowledge & 3,880 & 5,086 & 25,205 & 28,858 & $31 \%$ & $14 \% *$ & 644 \\
\hline Office & 8,281 & 8,877 & 77,590 & 77,023 & $7 \%$ & $-1 \% *$ & 657 \\
\hline Education & 33 & 131 & 15,249 & 19,540 & $297 \%$ & $28 \% *$ & 89 \\
\hline Health & 3,757 & 3,172 & 18,591 & 21,868 & $-16 \%$ & $18 \% *$ & $(1,247)$ \\
\hline Arts-Ent-Rec & 2,844 & 2,147 & 9,534 & 9,627 & $-25 \%$ & $1 \% *$ & $(725)$ \\
\hline Total & 23,263 & 27,251 & 200,818 & 219,879 & $17 \%$ & $9 \% *$ & 1,900 \\
\hline
\end{tabular}


Table 5. Summary and comparison of four streetcar systems

\begin{tabular}{|c|c|c|c|c|c|c|c|}
\hline Name & Location & $\begin{array}{l}\text { "Before" } \\
\text { Date; } \\
\text { Date } \\
\text { Opened }\end{array}$ & Stations & $\begin{array}{l}\text { Control } \\
\text { area } \\
\text { employ } \\
\text { ment } \\
\text { growth }\end{array}$ & $\begin{array}{l}\text { Street- } \\
\text { car } \\
\text { area } \\
\text { employ } \\
\text { ment } \\
\text { growth }\end{array}$ & $\begin{array}{l}\text { Employment } \\
\text { Growth Sectors }\end{array}$ & $\begin{array}{l}\text { Surrounding } \\
\text { influential land } \\
\text { use }\end{array}$ \\
\hline $\begin{array}{l}\text { Central } \\
\text { Loop } \\
\text { (Phase II) }\end{array}$ & $\begin{array}{l}\text { Portland } \\
\text { OR }\end{array}$ & $\begin{array}{l}\text { 2006; } \\
2012 \\
\text { (bridge } \\
\text { opened } \\
2015 \text { ) }\end{array}$ & $\begin{array}{l}\text { (1) NE Grand } \\
+ \text { Holladay } \\
\text { (2) Grand + } \\
\text { Stark (3) SE } \\
\text { Grand } \\
\text { Hawthorne }\end{array}$ & $8 \%$ & $22 \%$ & $\begin{array}{l}\text { Knowledge, Retail- } \\
\text { Lodging-Food, } \\
\text { Health }\end{array}$ & $\begin{array}{l}\text { Crossing bridge, } \\
\text { Convention Ctr, } \\
\text { Lloyd District, } \\
\text { aging industrial, } \\
\text { County Admin }\end{array}$ \\
\hline S-Line & $\begin{array}{l}\text { Salt Lake } \\
\text { City UT }\end{array}$ & $\begin{array}{l}2009 ; \\
2013\end{array}$ & $\begin{array}{l}\text { (1) Fairmont } \\
\text { (2) } 500 \text { East } \\
\text { (3) South Salt } \\
\text { Lake }\end{array}$ & $25 \%$ & $-2 \%$ & Office & $\begin{array}{l}\text { Linear park, bike } \\
\text { path, park-and- } \\
\text { ride lots, major } \\
\text { commercial ctr, } \\
\text { aging industrial }\end{array}$ \\
\hline $\begin{array}{l}\text { South } \\
\text { Lake } \\
\text { Union }\end{array}$ & $\begin{array}{l}\text { Seattle } \\
\text { WA }\end{array}$ & $\begin{array}{l}2003 ; \\
2007\end{array}$ & $\begin{array}{l}\text { (1) Westlake } \\
\text { Hub } \\
\text { (2) Westlake } \\
\text { Ave + } \\
\text { Thomas St (3) } \\
\text { Fairview Ave } \\
\text { + Campus Dr }\end{array}$ & $27 \%$ & $-1 \%$ & $\begin{array}{l}\text { Health, Arts- } \\
\text { Entertainment- } \\
\text { Recreation }\end{array}$ & $\begin{array}{l}\text { Amazon } \\
\text { campus, other } \\
\text { corporate HQ's, } \\
\text { biotechnology/ } \\
\text { biomedical } \\
\text { research, } \\
\text { museums }\end{array}$ \\
\hline $\begin{array}{l}\text { Rampart- } \\
\text { St. Claude }\end{array}$ & $\begin{array}{l}\text { New } \\
\text { Orleans } \\
\text { LA }\end{array}$ & $\begin{array}{l}2008 ; \\
2013\end{array}$ & $\begin{array}{l}\text { (1) Union } \\
\text { Passenger } \\
\text { Terminal (2) } \\
\text { Rampart-St. } \\
\text { Claude Ave + } \\
\text { Poydras St } \\
\text { (3) Canal St + } \\
\text { Elk }\end{array}$ & $-3 \%$ & $17 \%$ & $\begin{array}{l}\text { Office, Retail- } \\
\text { Lodging-Food }\end{array}$ & $\begin{array}{l}\text { Bus terminal, } \\
\text { CBD, Surface } \\
\text { parking lots, } \\
\text { entertainment } \\
\text { district }\end{array}$ \\
\hline
\end{tabular}




\section{Appendix Table 1 - Streetcar Planning Policies}

\begin{tabular}{|c|c|c|c|c|c|}
\hline City & Streetcar line & Policies & Intended Effect of policies & Additional incentives & Source \\
\hline \multirow[t]{5}{*}{$\begin{array}{l}\text { Salt } \\
\text { Lake } \\
\text { City }\end{array}$} & S-Line & $\begin{array}{l}\text { Zoning: High } \\
\text { Density Mixed } \\
\text { Use and } \\
\text { Residential }\end{array}$ & $\begin{array}{l}\text { High density near transit stops to } \\
\text { increase accessibility and transit } \\
\text { ridership }\end{array}$ & & $\begin{array}{l}\text { East Streetcar Neighborhood Form } \\
\text { Based Code }\end{array}$ \\
\hline & & $\begin{array}{l}\text { Design standard: } \\
\text { Implementation } \\
\text { of greenway } \\
\text { along streetcar } \\
\text { line }\end{array}$ & $\begin{array}{l}\text { a multi-use corridor to increase } \\
\text { access and attract new } \\
\text { businesses, residents, and } \\
\text { visitors }\end{array}$ & & $\begin{array}{l}\text { Downtown South Salt Lake } \\
\text { Zoning Ordinance and Design } \\
\text { Standards }\end{array}$ \\
\hline & & $\begin{array}{l}\text { East Streetcar } \\
\text { Neighborhood } \\
\text { Form Based } \\
\text { Code }\end{array}$ & $\begin{array}{l}\text { Transit-oriented redevelopment } \\
\text { near streetcar corridor }\end{array}$ & & $\begin{array}{l}\text { East Streetcar Neighborhood Form } \\
\text { Based Code }\end{array}$ \\
\hline & & & & $\begin{array}{l}\text { Suggested incentive programs: } \\
\text { First-time home buyer } \\
\text { assistance; Financing for public } \\
\text { improvements, such as lighting } \\
\text { or streets; Financial partnership } \\
\text { to build housing that the city } \\
\text { desires such } \\
\text { as senior or workforce housing; } \\
\text { Financial partnership on shared } \\
\text { parking; Rental unit buy back }\end{array}$ & East Streetcar Master Plan \\
\hline & & $\begin{array}{l}\text { Streetcar } \\
\text { Community } \\
\text { Development } \\
\text { Area (CDA) } \\
\end{array}$ & $\begin{array}{l}\text { negotiate participation terms } \\
\text { with taxable entities in CDA }\end{array}$ & & $\begin{array}{l}\text { South Salt Lake Economic } \\
\text { Development Report }\end{array}$ \\
\hline
\end{tabular}




\section{Appendix - Streetcar Planning Policies continued}

\begin{tabular}{|c|c|c|c|c|c|}
\hline City & Streetcar line & Policies & Intended Effect of policies & Additional incentives & Source \\
\hline \multirow[t]{3}{*}{ Portland } & $\begin{array}{l}\text { Central Loop } \\
\text { (Phase II) }\end{array}$ & $\begin{array}{l}\text { Central } \\
\text { Employment } \\
\text { Zone }\end{array}$ & $\begin{array}{l}\text { Mixed use of commercial and } \\
\text { industrial buildings in a central } \\
\text { location with transit access that } \\
\text { matches existing development; }\end{array}$ & & Portland Zoning Code \\
\hline & & $\begin{array}{l}\text { Central } \\
\text { Commercial } \\
\text { Zone }\end{array}$ & $\begin{array}{l}\text { Intense development with high } \\
\text { building coverage, large } \\
\text { buildings, close spacing, and } \\
\text { pedestrian oriented with } \\
\text { attractive streetscapes }\end{array}$ & & Portland Zoning Code \\
\hline & & & & $\begin{array}{l}\text { Streetcar installation expected as } \\
\text { development catalyst }\end{array}$ & $\begin{array}{l}\text { Portland Streetcar Loop } \\
\text { Development Strategy }\end{array}$ \\
\hline
\end{tabular}




\section{Appendix - Streetcar Planning Policies continued}

\begin{tabular}{|c|c|c|c|c|c|}
\hline City & Streetcar line & Policies & Intended Effect of policies & Additional incentives & Source \\
\hline \multirow[t]{4}{*}{ Seattle } & $\begin{array}{l}\text { South Lake } \\
\text { Union }\end{array}$ & $\begin{array}{l}\text { Incentive zone } \\
\text { overlay }\end{array}$ & $\begin{array}{l}\text { Provide affordable housing or } \\
\text { other public amenities }\end{array}$ & $\begin{array}{l}\text { Developers gain extra floor area } \\
\text { within their project by providing } \\
\text { external amenities }\end{array}$ & $\begin{array}{l}\text { Seattle Municipal Code; Incentive } \\
\text { Zoning Overview, City of Seattle } \\
\text { Office of Housing }\end{array}$ \\
\hline & & $\begin{array}{l}\text { Seattle Mixed } \\
\text { Zone }\end{array}$ & $\begin{array}{l}\text { Higher density and transit- } \\
\text { supportive residential, } \\
\text { commercial, and office uses will } \\
\text { redevelop industrial areas }\end{array}$ & & Seattle Municipal Code \\
\hline & & $\begin{array}{l}\text { Downtown } \\
\text { Mixed Zone }\end{array}$ & $\begin{array}{l}\text { Urban center with mixed uses } \\
\text { supporting transit and pedestrian } \\
\text { orientation }\end{array}$ & & Seattle Municipal Code \\
\hline & & $\begin{array}{l}\text { Downtown } \\
\text { Office Core } \\
\text { Zone }\end{array}$ & $\begin{array}{l}\text { High density office and } \\
\text { commercial land uses due to } \\
\text { higher building heights take the } \\
\text { place of older office and light } \\
\text { manufacturing areas }\end{array}$ & & Seattle Municipal Code \\
\hline
\end{tabular}




\section{Appendix - Streetcar Planning Policies continued}

\begin{tabular}{|c|c|c|c|c|c|}
\hline City & Streetcar line & Policies & Intended Effect of policies & Additional incentives & Source \\
\hline \multirow[t]{3}{*}{$\begin{array}{l}\text { New } \\
\text { Orleans }\end{array}$} & $\begin{array}{l}\text { Rampart-St. } \\
\text { Claude }\end{array}$ & $\begin{array}{l}\text { Current Zoning: } \\
\text { Commercial } \\
\text { streetcar corridor } \\
\text { now exists for } \\
\text { the buildings } \\
\text { fronting the } \\
\text { streetcar. }\end{array}$ & $\begin{array}{l}\text { High density commercial } \\
\text { buildings along streetcar line } \\
\text { will boost economic } \\
\text { development in the area. }\end{array}$ & & $\begin{array}{l}\text { City of New Orleans Property } \\
\text { Viewer \& Comprehensive Zoning } \\
\text { Ordinance }\end{array}$ \\
\hline & & $\begin{array}{l}\text { Design standard } \\
\text { for central } \\
\text { commercial and } \\
\text { historic } \\
\text { commercial }\end{array}$ & $\begin{array}{l}\text { Promotes historic preservation } \\
\text { and tourist traffic in the area }\end{array}$ & & $\begin{array}{l}\text { City of New Orleans Vieux Carre } \\
\text { Design Guidelines }\end{array}$ \\
\hline & & & & $\begin{array}{l}\text { Streetcar implementation } \\
\text { expected to be a catalyst for } \\
\text { commercial/private development } \\
\text { and to bring economic profit to } \\
\text { the area by increasing property } \\
\text { taxes and promoting tourist } \\
\text { traffic }\end{array}$ & $\begin{array}{l}\text { Mayor Landrieu and RTA's press } \\
\text { release 10/03/16: } \\
\text { https://www.nola.gov/mayor/press- } \\
\text { releases/2016/20161003-pr- } \\
\text { rampart-st-claude-line-opening/ }\end{array}$ \\
\hline
\end{tabular}

